\title{
Mechanism of Green Supply Chain: In the Manufacturing Industry of U.S
}

\author{
S. A. Rehman ${ }^{1, ~ *, ~ Y u ~ Z h a n g ' ~}{ }^{2}$, S. Shahid ${ }^{3}$ \\ ${ }^{1}$ School of Supply Chain and Management, Chang'an University, Xi'an, China \\ ${ }^{2}$ School of Printing and Packaging, Xi' an University of Technology, Xi' an, China \\ ${ }^{3}$ School of Foreign Languages, Happy Home Foundation, Karachi, Pakistan
}

Email address:

984730042@qq.com (S. A. Rehman)

${ }^{*}$ Corresponding author

\section{To cite this article:}

S. A. Rehman, Yu Zhang, S. Shahid. Mechanism of Green Supply Chain: In the Manufacturing Industry of U.S. Advances in Applied Sciences. Vol. 2, No. 5, 2017, pp. 87-92. doi: 10.11648/j.aas.20170205.16

Received: February 9, 2017; Accepted: March 3, 2017; Published: October 30, 2017

\begin{abstract}
In last couple of decades, green supply chain become a competitive strategy for survival in tough competitive market. There is no doubt that a number of European countries already adopted green supply chain practices successfully. Green supply chain concept gives a way to conduct a sustainable business and also prevent to environments from harmful effects of chemicals and pollution. On the other hand, green supply chain also reduce the cost of the end-to-end supply chain [1]. Many visible and invisible factors are exists in the process of reverse logistics but main factors are social reasons, Economic, Legal \& Environment policies. But the economic factor is the directly involve in the implementation of reverse logistics. This paper will help to understand the phenomena involved in green supply chain management implementation as well as the barriers and drivers involved in green supply chain execution phases.
\end{abstract}

Keywords: Green Supply Chain, Manufacturing Industry, Recycle, Repair, Reuse

\section{Introduction}

According to researchers, in last few decades reverse logistics is become more important for the all stake holder of supply chain management [2]. Before management was taking "reverse logistics as an expense" and they through reverse logistics is only carry huge investments without return. But now companies have observed that's "reverse logistics play an vital role in companies profitable". And that is true, if companies use reverse logistics carefully so they can save big amount, reverse logistics in the green supply chain is the process of "reverse flow of Goods". In the reverse logistics typically re-manufacturing and refurbishment may also include. Reverse logistics is also include damaged goods, returned goods or material from customer, excess inventory. In the U.S economy reverse logistics has a significant portion almost $11 \%$ approximately and every year it is growing. These reverse logistics magnitude is depend over the industry to industry, company to company as well as firm's channel choice, means which channel they are using for reverse logistics. Reverse logistics is simply recovery of value from goods; it is the vital spirit of reverse logistics [3].

These framework is help to understanding the reverse logistics phenomena, and stages, after the sorting of goods, the concern person decide whether this goods will go directly for sale (reuse), or its required further work under the head of repair, recycling, refurbishment or it will go for the disposal in landfill' side.

This research will help to identify the barriers of reverse logistics face by manufacturing companies in USA. Due to benefits associated in reverse logistics, in today's world almost every firm has been involved in the phenomena of reverse logistics, there is no any argument that's many manufacturing companies face barriers and challenges in reverse logistics. Many researchers and supply chain professionals are religiously working on the visible and invisible benefits of reverse logistics. In this research the 
major source of information is Supply Chain Directors \& Managers of manufacturing companies, and data will be collected by structured-Questionnaire.

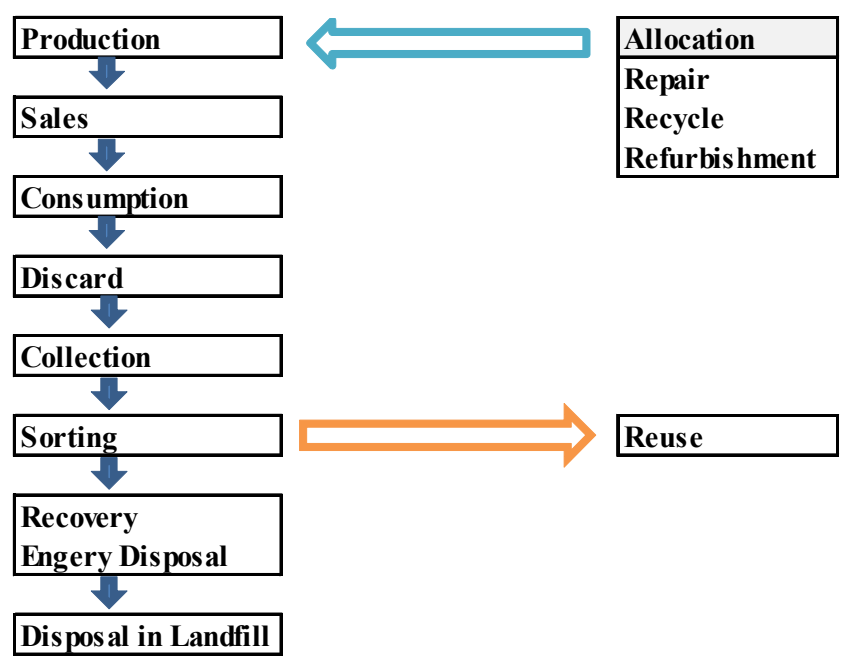

Figure 1. The Conceptual Frame Work of Reverse Logistics.

\section{Literature Review \& Theoretical Background}

The APICS Dictionary $14^{\text {th }}$ Edition "A flow of material and goods from the destination to origin, and the purpose of this flow are usually recycling, re-manufacturing, returns and repair". There is no any argument reverse logistics is not new concept, but it become more prominent after 1980s. Reverse logistics simply can explain as the Plan, implement and then control to the flow of backward raw material \& goods [1]. Many visible and invisible factors are exists in the process of reverse logistics but main factors are social reasons, Economic, Legal \& Environment policies. But the economic factor is the directly involve in the implementation of reverse logistics.

The concept of reverse logistics remains an evolving one. There is no doubt that the concept of reverse logistics has always been in place; however, the usage of reverse logistics became prominent in 1980s. Reverse logistics can easily be defined as one of the most important processes that plans, implements and control the backward flows of raw material [1]. This is majorly done in the process inventory, packaging and finishing of goods within an aim to manufacture or distribute, to a point of recovery or point of appropriate disposal. In simple words, recovery of value is the basic essence of reverse logistics. There are many reasons for implementing or operating through the reverse logistics systems. Economic, legal, and social reasons are the important. These also called triple bottom line. In 1994 first time triple bottom line concept coined by John Elkington, every company should develop three different bottom lines; it was the argument of Mr. Elkington. And these three bottom line graphical representation is given below.

So ultimately triple bottom line concept is also support to the reverse logistics process but the economic reasons are the direct reasons behind the popularity of reverse logistics. Reverse logistics essentially helps in reduction of disposal costs and the usage of raw materials. People usually wonder about the logic behind involving in the process of reverse logistics [2].

The reverse logistics is not necessary will start from Consumer side, reverse logistics can be start from partner in the supply chain including distributor or retailer, but if consumer returned to goods so it's usually because of damaged, defective goods, repair etc. but usually supply chain partner return to the goods because of excess product stock (over ordered), after promotion activity, damaged in transit, out of shelf life, expiry of products, or products are failed to sales.

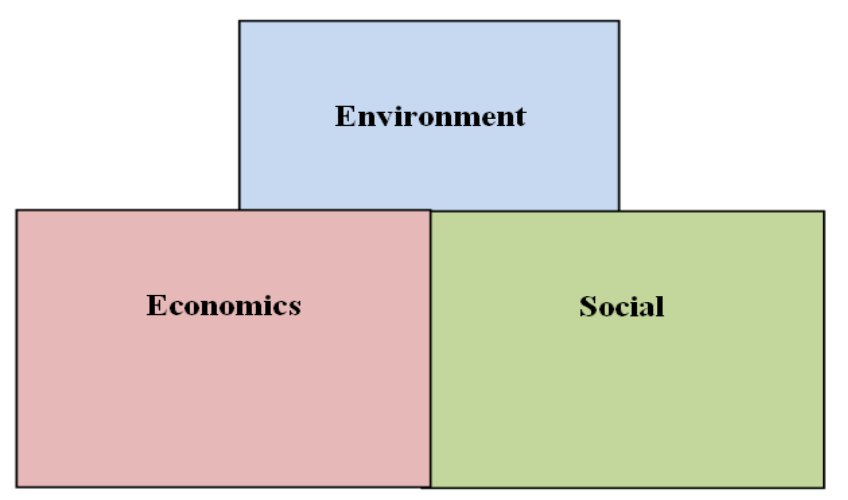

Figure 2. Triple Bottom Lines.

In the U.S. market limited usage of reusable packaging, because many companies are using reverse logistics for the products purpose only, but for this perception one exception exists "like firms use reusable containers". In many countries companies have legal binding to use appropriate recovery of waste or disposal in landfill like the companies of European Union, as well as social reasons is also play very important role, because if company use reverse logistics so indirectly they are sending message to consumer that's "they are vigilant, and they are environment friendly" and this perception give space to the company in society for the speedy growth and reverse logistics also converting to companies towards environment friendly $[1,4]$.

Table 1. Sources of Reverse Goods Flows.

\begin{tabular}{lll}
\hline \multirow{4}{*}{ Products } & Consumers/ End Users & Supply Chain Partners \\
\cline { 2 - 3 } & Defective Products. & Over Stock Returns. \\
& Repair, Warranty. & Marketing Returns. \\
& Disposal for Environmental & In-Transit Damage \\
& Friendly. & Multi-Trip Packaging \\
\multirow{3}{*}{ Packaging } & Reuse. & Recycling. \\
& Disposal Restrictions & Disposal Requirements \\
\hline
\end{tabular}

\subsection{Reverse Logistics \& Manufacturing Sector}

The top priority factor of reverse logistics in manufacturing sectors are, "to reduce the production Costs" which is almost $26 \%$ and on the second is Environmental Friendly which is almost $18 \%$ [5]. But there is still gap exists 
to analyze the more benefits of reverse logistics for the manufacturing sectors, because still many companies have not implemented the reverse logistics in the manufacturing firms. Reverse logistics bear almost $3 \%$ to $4 \%$ of the total logistics cost in the companies [6-7]. And if company implement reverse logistics in proper manners so they can save $10 \%$ approximately every year. Companies like General Motors, Pepsi Co. and Procter \& Gamble these are the few industry leaders, who has implemented reverse logistics perfectly in their companies supply chain management, from the last few decades reverse logistics is growing very fast, because now many companies has understood the reverse logistics importance for the operations of their businesses [89]. But researcher has observed still there are many barriers face by manufacturing sector during effective implementation of reverse logistics.

In the 2007 the financial crunch and down turn in the U.S economy and many people has lost their jobs, but now once again manufacturing sector is growing after very bad time in last few years. And U.S is produced $21 \%$ of the World manufacturing output. The U.S is the second largest manufacturing industries in the world by revenue include: Food, Consumer goods, mining, Telecommunication, Chemicals, Electronics, Automobiles, Aerospace, Lumber, Petroleum and Steel. In the 2010 the U.S manufacturing industries output was 1,696.7 Billion US Dollar Approximately.

\subsection{Major Challenges Face in Reverse Logistics}

In the supply chain of manufacturing firms, there are many different challenges exists in implementation phase of reverse logistics. According to the Chan, Chan \& Jain and Demirel \& Gokcen, Manufacturing Companies are hesitate to implement the reverse logistics process in the supply chain [8-9]. And few major barriers which face in the implementation phase of reverse logistics are following.

- According to the Chan, Chan \& Jain, it is very general perception in the mind of customer that's "remanufacture products are less effective than newly manufactured" [8]. And this perception is become as a barrier in implementation of reverse logistics, because of this customer perception; companies are not willingness to invest in the process of reverse logistics. companies if sale re-manufactured products on low price so consumer thinks "this product is cheap because of low quality" so only very few percentage of consumers are willingness to buy re-manufactured products, so ultimately companies are reserved from investing in the process of logistics [9].

- One major challenge face in the process of reverse logistics implementation is "Cannibalization". Because if companies are selling re-manufactured products and consumers buy re-manufactured products because its low cost, so ultimately newly manufactured products are unable to sale, means re-manufactured products are sold on the expense of newly manufactured products, benefits of underlying associated in the products of re- manufacturing can outsider the cost of cannibalization [6].

- Companies financial conditions can also impact over reverse logistics process, because in the phase of reverse logistics manufacturing firms need financial support to develop a proper and efficient system to handle the process of reverse logistics [10].

- According to Ravi, In the competitive environment of today's world, where new technology and designs (products) are innovating, it is difficult for the companies to work and keep focus on the process of reverse logistics [9].

- Another important barrier is perception of customers, because understanding the behavior of customer is very important. And in this regards. Usually consumers not only focus on cheap and low price, but they also need satisfaction from the quality side of products [10]. In the sale of re-manufactured products the customer perception has a direct impact, customers usually perceived re-manufactured products have low quality [11]. So if customer or consumer are not agree to buy re-manufactured products not because of any tangible reasons but because of perception.

- According to the researchers Information Technology is called the backbone of the supply chain management, As well information technology is crucial to support efficient and effective reverse logistics. If manufacturing firms are using good IT system, so they can easily overcome many barriers like inaccuracy in the information, fast flow of information. As per the CSCP (Edition 2014) body of knowledge APCIS Operation \& Management Chicago USA, The concept of $3 \mathrm{VS}$ (visibility, velocity and variability) are very important in the supply chain. It means if Visibility+ Velocity will be increase so ultimately over all variability will be decrease from the whole supply chain $[5,7]$.

- In the reverse logistics implementation "Lack of support" is also play a vital role. Many times supply chain partners: Retailers, Distributors are not supporting to the re-manufactured products and they do not push these products towards consumers. Because lack of interest, in the re-manufactured items, retailers and distributors have very little profit margin, so lack of support from retailers and distributors are also can a disaster role in the reverse logistics process $[9,11]$.

\section{Methodology}

In writing effective research paper selecting the appropriate research methodology is very important, and this research will help to identify the drivers and barriers of reverse logistics face by manufacturing industry in USA. In the USA many manufacturing companies are well developed. But not all the manufacturing companies are using reverse logistics in their supply chain because of the barriers and challenges associated. For collecting the data for the 
research, we are going to use primary quantitative (firsthand) techniques. And we will survey almost 200 Supply chain Director and senior management people from different manufacturing companies to fulfill the purpose of this research. And the purpose of this research is to identify the barriers and challenges face by manufacturing industry in USA during implementation phase of reverse logistics. The data will be collected by surveyed (structured Questionnaire) from the relevant directors and senior managers of the manufacturing companies. After the collection of data the Descriptive Statistics will use for the representation of important findings and research results. Descriptive statistics is very important in representation of data, because if researcher wants to presents some findings so it is difficult to show results from raw data, and it is become more difficult when data is in very large numbers, so this problem solve by descriptive statistics and descriptive statistics represents the data in more meaningful way.

\section{Results/Findings}

The first hand (primary) data has been collected by surveyed from 200 Directors and senior managers of manufacturing industry. And these data will be used to identify the importance of reverse logistics challenges face by manufacturing firms in US.

Table 2. Supply chain of manufacturing industry.

\begin{tabular}{|c|c|c|c|c|c|c|c|c|}
\hline & $\mathbf{N}$ & Range & Minimum & Maximum & Mean & & Std. Deviation & Variance \\
\hline & Statistic & Statistic & Statistic & Statistic & Statistic & Std. Error & Statistic & Statistic \\
\hline $\begin{array}{l}\text { 4. How will you rank, the relevancy of reverse } \\
\text { logistics concept in the supply chain of } \\
\text { manufacturing industry? ( } 0 \text { being the lowest and } 4 \\
\text { being the highest rank). }\end{array}$ & 200 & 4.00 & .00 & 4.00 & 1.3250 & .06907 & .97680 & .954 \\
\hline Valid N (list wise) & 200 & & & & & & & \\
\hline
\end{tabular}

In the supply chain, the importance of reverse logistics, this question asked. All most the entire respondent's well knows aware about the reverse logistics importance in the manufacturing firm's supply chain management. Its means reverse logistics is becoming more important in the manufacturing firms, with the passage of time.

Table 3. The implementation of reverse logistics.

\begin{tabular}{|c|c|c|c|c|c|c|c|c|}
\hline & $\mathbf{N}$ & Range & Minimum & Maximum & Mean & & Std. Deviation & Variance \\
\hline & Statistic & Statistic & Statistic & Statistic & Statistic & Std. Error & Statistic & Statistic \\
\hline $\begin{array}{l}5 \text {. The performance of your company improved } \\
\text { by the implementation of reverse logistics? }\end{array}$ & 200 & 1.00 & .00 & 1.00 & .1700 & .02663 & .37658 & .142 \\
\hline Valid N (list wise) & 200 & & & & & & & \\
\hline
\end{tabular}

The performance of manufacturing firms improved by the implementation of reverse logistics, this question asked from the relevant concerns, and many respondents was agreed and accept that's company performance has been increased by implementation of reverse logistics in the supply chain of manufacturing firms. So this aspect shows the significance of reverse logistics.

Table 4. Barriers and challenges in reverse logistics of manufacturing industry.

\begin{tabular}{|c|c|c|c|c|c|c|c|c|}
\hline & $\mathbf{N}$ & Range & Minimum & Maximum & Mean & & Std. Deviation & Variance \\
\hline & Statistic & Statistic & Statistic & Statistic & Statistic & Std. Error & Statistic & Statistic \\
\hline $\begin{array}{l}\text { 6. Barriers and Challenges in reverse logistics of } \\
\text { manufacturing industry really create problems in its } \\
\text { effective implementation? ( } 0 \text { being the lowest and } 4 \\
\text { being the highest rank). }\end{array}$ & 200 & 3.00 & .00 & 3.00 & .6950 & .07060 & .99848 & .997 \\
\hline Valid N (list wise) & 200 & & & & & & & \\
\hline
\end{tabular}

The challenges face by manufacturing firms in the industry of manufacturing. This question asked from the respondents. Mostly directors and senior manager of supply chain was agreed that's. There are significance challenges are associated with the implementation of reverse logistics in the manufacturing industry.

Table 5. Willingness to pay for remanufactured products.

\begin{tabular}{|c|c|c|c|c|c|c|c|c|}
\hline & $\mathbf{N}$ & Range & Minimum & Maximum & Mean & & Std. Deviation & Variance \\
\hline & Statistic & Statistic & Statistic & Statistic & Statistic & Std. Error & Statistic & Statistic \\
\hline $\begin{array}{l}\text { 7. Behind the less utilization of reverse logistics, } \\
\text { due to the less willingness to pay for re- } \\
\text { manufactured products? ( } 0 \text { being the lowest and } 4 \\
\text { being the highest rank). }\end{array}$ & 200 & 4.00 & .00 & 4.00 & 1.3700 & .06884 & .97357 & .948 \\
\hline Valid N (list wise) & 200 & & & & & & & \\
\hline
\end{tabular}

The questions asked regarding the less utilization of reverse logistics, due to less willingness to pay for re-manufactured 
products, and the answer was clearly shows that's less willingness to pay for re-manufactured products is a big hurdle for manufacturing industries, when they come up at the phase of implementation of reverse logistics process.

Table 6. Cannibalization of products sales.

\begin{tabular}{|c|c|c|c|c|c|c|c|c|}
\hline & $\mathbf{N}$ & Range & Minimum & Maximum & Mean & & Std. Deviation & Variance \\
\hline & Statistic & Statistic & Statistic & Statistic & Statistic & Std. Error & Statistic & Statistic \\
\hline $\begin{array}{l}\text { 8. In the manufacturing industry, the cannibalizatio } \\
\text { of products (new) sales can occur because off } \\
\text { reverse logistics? ( } 0 \text { being the lowest and } 4 \text { being } \\
\text { the highest rank). }\end{array}$ & 200 & 4.00 & .00 & 4.00 & 1.7900 & .06558 & .92747 & .860 \\
\hline Valid N (list wise) & 200 & & & & & & & \\
\hline
\end{tabular}

The question asked, about the cannibalization of products sales can occur because off reverse logistics in the manufacturing industry. So answer was "cannibalization is an importance challenge", almost all respondents were agreed.

Table 7. Increasing competition in the market and company financial scarcity.

\begin{tabular}{|c|c|c|c|c|c|c|c|c|}
\hline & $\mathbf{N}$ & Range & Minimum & Maximum & Mean & & Std. Deviation & Variance \\
\hline & Statistic & Statistic & Statistic & Statistic & Statistic & Std. Error & Statistic & Statistic \\
\hline $\begin{array}{l}\text { 9. In the manufacturing industry, increasing } \\
\text { competition in the market and company financial } \\
\text { scarcity is also creates significance impact over the } \\
\text { implementation of reverse logistics? ( } 0 \text { being the } \\
\text { lowest and } 4 \text { being the highest rank). }\end{array}$ & 200 & 4.00 & .00 & 4.00 & 1.7600 & .06621 & .93637 & .877 \\
\hline Valid N (list wise) & 200 & & & & & & & \\
\hline
\end{tabular}

The question asks regarding increasing competition in the market and financial scarcity of firms can also create significance impact over the implementation of effective reverse logistics process. So relevant supply chain concerns were strong agreed, and because of increasing competition, reverse logistics implementation is become difficult.

Table 8. Negative perception about remanufactured products in the consumer mind.

\begin{tabular}{|c|c|c|c|c|c|c|c|c|}
\hline & $\mathbf{N}$ & Range & Minimum & Maximum & Mean & & Std. Deviation & Variance \\
\hline & Statistic & Statistic & Statistic & Statistic & Statistic & Std. Error & Statistic & Statistic \\
\hline $\begin{array}{l}\text { 10. In the manufacturing industry, Negative } \\
\text { perception about re-manufactured products in the } \\
\text { consumer mind, is a barrier and challenge? ( } 0 \\
\text { being the lowest and } 4 \text { being the highest rank). }\end{array}$ & 200 & 4.00 & .00 & 4.00 & 1.2800 & .05980 & .84568 & .715 \\
\hline
\end{tabular}

This question considered the perception of customers of regarding re-manufactured products also create significance impact over reverse logistics in the supply chain management of manufacturing industry, so respondents agreed, and because of negative perception about re-manufactured products, it is become challenge and barriers for the implementation of reverse logistics in the supply chain of manufacturing industry.

able 9. The adoption and implementation of reverse logistics.

\begin{tabular}{|c|c|c|c|c|c|c|c|c|}
\hline & $\mathbf{N}$ & Range & Minimum & Maximum & Mean & & Std. Deviation & Variance \\
\hline & Statistic & Statistic & Statistic & Statistic & Statistic & Std. Error & Statistic & Statistic \\
\hline $\begin{array}{l}\text { 14. In the manufacturing industry. The adoption and } \\
\text { implementation of reverse logistics is also hinder by } \\
\text { the lack of support from Supply Chain Partners \& } \\
\text { Lack of IT systems? }\end{array}$ & 200 & 4.00 & .00 & 4.00 & 1.2800 & .05722 & .80924 & .655 \\
\hline Valid N (list wise) & 200 & & & & & & & \\
\hline
\end{tabular}

The question asked about lack of support from supply chain partners and the legacy Information Technology systems can create significance impact over the process of reverse logistics in manufacturing industry. So almost participants of this study was agreed that's if supply chain partners mainly retailers and distributors do not show the seriousness regarding the process of reverse logistics, so it is become very difficult.

\section{Discussion}

In this research as we conducted survey to identify the importance and challenges of reverse logistics in the manufacturing industry. And questionnaire developed purely to identify the challenges face by USA based manufacturing industry in the implementation phase of reverse logistics. In this research study from different manufacturing companies' supply 
chain director and senior manager did participate. Reverse logistics concept is becoming more important day by day. And there is no doubt effective reverse logistics can impact on overall supply chain performance positively. But many companies are unable to implement reverse logistics. The barrier face by manufacturing industry during effective implementation of reverse logistics is a big cause, that's why many manufacturing firms are using conservative approach for adopting the process of reverse logistics [2]. Every manufacturing firms do not have capability to overcome the barriers and challenges during the process of effective reverse logistics, as per the research results manufacturing firms in-fact do not try to implement reverse because off the lack of support from supply chain partners, cannibalization, financial scarcity, lack of IT system support, negative perception of customers [3]. Many consumers perceived re-manufactured products as a low quality. And it is crucial for the growth of reverse logistics, first change to the negative perceptions of consumers regarding re-manufactured products in manufacturing industry [10].

\subsection{Implication of Research}

The implication of this research, there are very significant barriers exists which creates disaster impact over implementation of reverse logistics in the manufacturing industry. The mainly the challenges which face by manufacturing industry has been identified in this research so senior management of supply chain before implementation phase of reverse logistics. They should gauge and work over those challenges, which can creates disaster impact in the process of reverse logistics. Usually has been seen that's supply chain managers are now well knows about the challenges of reverse logistics implementation in the manufacturing industry. As well as supply chain senior management can tackle those disaster challenges by making strategic decisions in the manufacturing firm, in the bottom line, senior management can realize the fruitful benefits associated with reverse logistics during implementation phase, and then they can also will motivated to tackle the challenges.

\subsection{Conclusion and Future Research}

In the supply chain management, reverse logistics is the complete procedure of transferring goods from their destination (final) to origin, these call reverse logistics including disposal in landfill after recovery of energy. In the manufacturing industry the importance of reverse logistics is continuously growing. In the manufacturing industry companies face many challenges during implementation of reverse logistics. So this research has been fulfill to those gap in previous decades studies, and identified the different challenges which was hidden before in the manufacturing industry. The major challenges which manufacturing industry face in the reverse logistics implementation are Cannibalization, Competition, Negative perception of consumers, lack of IT systems, Financial scarcity, lack of employee's skills, lack of support from supply chain partners (retailers and distributors etc.). These are the major barriers which creates trouble for the manufacturing firms during reverse logistics implementation phase, so senior management should think about these challenges before implementation of reverse logistics and they should go towards implementation phase with appropriate strategies in order to overcome and minimize to the barriers \& all challenges are highlighted in this research. Usually every research has their limitations, and "nothing is perfect" and each research has the aim to identify valid and reliable results. So cover to all aspects of topic is not possible for the researcher practically, in the manufacturing industry firm's face which challenges and hurdles to identify those challenges and barriers. These were the objective of this research. Because of resources, time and other factors, the research may have some limitations. Therefore, the future more research can be conducted to explore further challenges as well researcher can explore the more challenges of reverse logistics in new market with other than manufacturing industries.

\section{References}

[1] Rubio, S. \& Parra, B. (2014) Reverse Logistics: Overview and Challenges for Supply Chain Management; International Journal of Engineering Business Management

[2] Baenas, et al (2011). A study of reverse logistics flow management in vehicle battery industries in the midwest of the state of São Paulo (Brazil). Journal of Cleaner Production, 19 (2), 168-172

[3] Bai, C., \& Sarkis, J. (2013). Flexibility in reverse logistics: a framework and evaluation approach. Journal of Cleaner Production, 47, 306-316.

[4] Grabara, J. et al (2014). The benefits of reverse logistics. International Letters of Social and Humanistic Sciences, (15), 138-147.

[5] Lee, C. \& Lam, J. (2012) Managing reverse logistics to enhance sustainability of industrial marketing; Industrial Marketing Management.

[6] Aitken, J., \& Harrison, A. (2013). Supply governance structures for reverse logistics systems. International Journal of Operations \& Production Management, 33 (6), 745-764.

[7] Ravi, V. (2014). Reverse Logistics Operations in Automobile Industry: A Case Study Using SAP-LAP Approach. Global Journal of Flexible Systems Management, 15 (4), 295-303.

[8] Chan, F. T. et al (2012). A framework of reverse logistics for the automobile industry. International Journal of Production Research, 50 (5), 1318-1331.

[9] Demirel, E. et al (2014). A mixed integer linear programming model to optimize reverse logistics activities of end-of-life vehicles in Turkey. Journal of Cleaner Production.

[10] Khan, S. A. R., Dong, Q. L., \& Yu, Z. (2016). Research on the Measuring Performance of Green Supply Chain Management: In the Perspective of China. International Journal of Engineering Research in Africa, 27, 167-178.

[11] Ravi, V., \& Shankar, R. (2012). Evaluating alternatives in reverse logistics for automobile organizations. International Journal of Logistics Systems and Management, 12 (1), 32-51. 